\title{
STUDIES ON FOLIICOLOUS FUNGI XII NEW SPECIES, NEW RECORDS AND HYPERPARASITES
}

\author{
V.B. Hosagoudar \\ Microbiology Division, Tropical Botanic Garden and Research Institute, Palode, Thiruvananthapuram, Kerala 695562, India. \\ Email:hosagoudar@hotmail.com
}

\begin{abstract}
This paper deals with five foliicolous fungi including two hyperparasites. Of these, two species of genus Asterina are new, while Lembosia ormosiae is a new record to India. Acrodictys balladynae and Spiropes dialii are hyperparasites known for the first time from India.
\end{abstract}

\section{Keywords}

Foliicolous, fungi, hyperparasites, Kerala, new records, new species

\begin{abstract}
Abbreviations
HCIO - Herbarium Cryptogamae Indiae Orientalis, New Delhi

TBGT - Tropical Botanic Garden, Thiruvananthapuram
\end{abstract}

\section{Asterina lanneae V.B. Hosagoudar et A. Manojkumar} sp. nov.

(Fig. 1)

\section{Material examined}

Holotype: 4.x.2002, Placherry forest, Ranni, Pathanamthitta, Kerala, India, on leaves of Lannea coromandelica (Houtt.) Merr. (Anacardiaceae), coll. A. Manojkumar, HCIO 44616 (p.p.). Isoptype: TBGT 898 (p.p.).

\section{Etymology}

Named after the host genus Lannea.

\section{Diagnostic features}

Coloniae epiphyllae, densae, crustosae, ad $5 \mathrm{~mm}$ diameter, confluentes. Hyphae rectae vel subrectae, plerumque opposite acuteque ramosae, laxe vel dense reticulatae, cellulae 14-18 $x$ 3-5 $\mathrm{m}$. Appressoria opposita, ad 10\% solitaries vel unilateralis, ovata, conoidea, integra vel variae lobata, 8 $10 \times 4-7 \mu \mathrm{m}$. Thyriothecia dispersa vel aggregata, connata, orbicularis, ad $200 \mu \mathrm{m}$ diameter, margine fimbriatae vel crenatae, hyphae fringiorae paucae, flexuosae, stellato dehiscentes ad centro; asci globosi, octospori, 30-40 $\mu \mathrm{m}$ diameter; ascosporae conglobatae, brunneae, uniseptatae, 19-21 × 9-11 $\mathrm{m}$, parietus punctatus.
Colonies epiphyllous, dense, crustose, up to $5 \mathrm{~mm}$ in diameter, confluent. Hyphae straight to substraight, branching mostly opposite at acute angles, loosely to closely reticulate, cells 14$18 \times 3-5 \mu \mathrm{m}$. Appressoria opposite, about $10 \%$ solitary or unilateral, ovate, conoid, entire to variously lobed, 8-10 x 4$7 \mu \mathrm{m}$. Thyriothecia scattered to grouped, often connate, orbicular, up to $200 \mu \mathrm{m}$ in diameter, margin fimbriate to crenate, fringed hyphae few, flexuous, stellately dehisced at the centre; asci globose, octosporous, $30-40 \mu \mathrm{m}$ in diameter; ascospores conglobate, brown, uniseptate, 19-21 x 9-11 $\mu \mathrm{m}$, wall punctate.

\section{Remarks}

Asterina anacardii (Ryan) Hosagoudar and Abraham, A. drimycarpi Kar and Maity and $A$. nothopegiae Ryan are known on the members of Anacardiaceae (Hosagoudar \& Abraham, 2000). Opposite and conoid appressoria of Asterina lanneae is similar to A. nothopegiae Ryan known on Nothopegia species from India (Ryan, 1928; Hosagoudar et al., 1996). However, the new species differs from it in having mostly opposite but $10 \%$ solitary appressoria, shorter ascospores with punctate wall. 


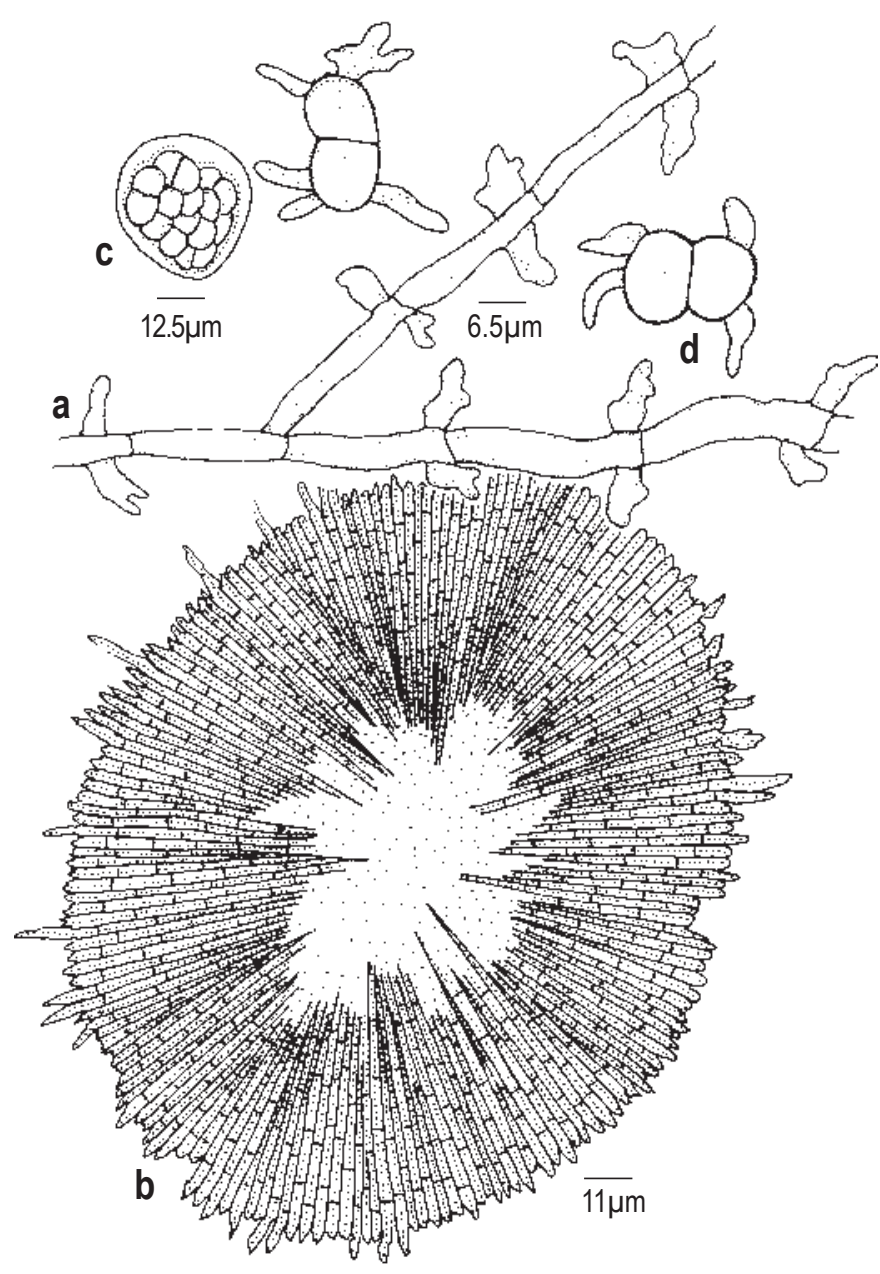

Figure 1. Asterina lanneae sp. nov.

a - Appressoriate mycelium; b - Thyriothecium; c - Ascus; $d$ - Ascospores

Asterina samaderae V.B. Hosagoudar et A. Manojkumar, sp. nov.

(Fig. 2)

\section{Material examined}

Holotype: 3.x.2002, Vandanam Sacred Grove, Alapuzha, Kerala, India, on leaves of Samadera indica Gaertn. (Simaroubaceae), coll. A. Manojkumar, HCIO 44615.

Isotype: TBGT 897.

\section{Etymology}

Named after the host genus Samadera.

\section{Diagnostic features}

Coloniae hypophyllae, subdensae, patentiae, ad $5 \mathrm{~mm}$ diameter, confluentes. Hyphae rectae, subrectae vel

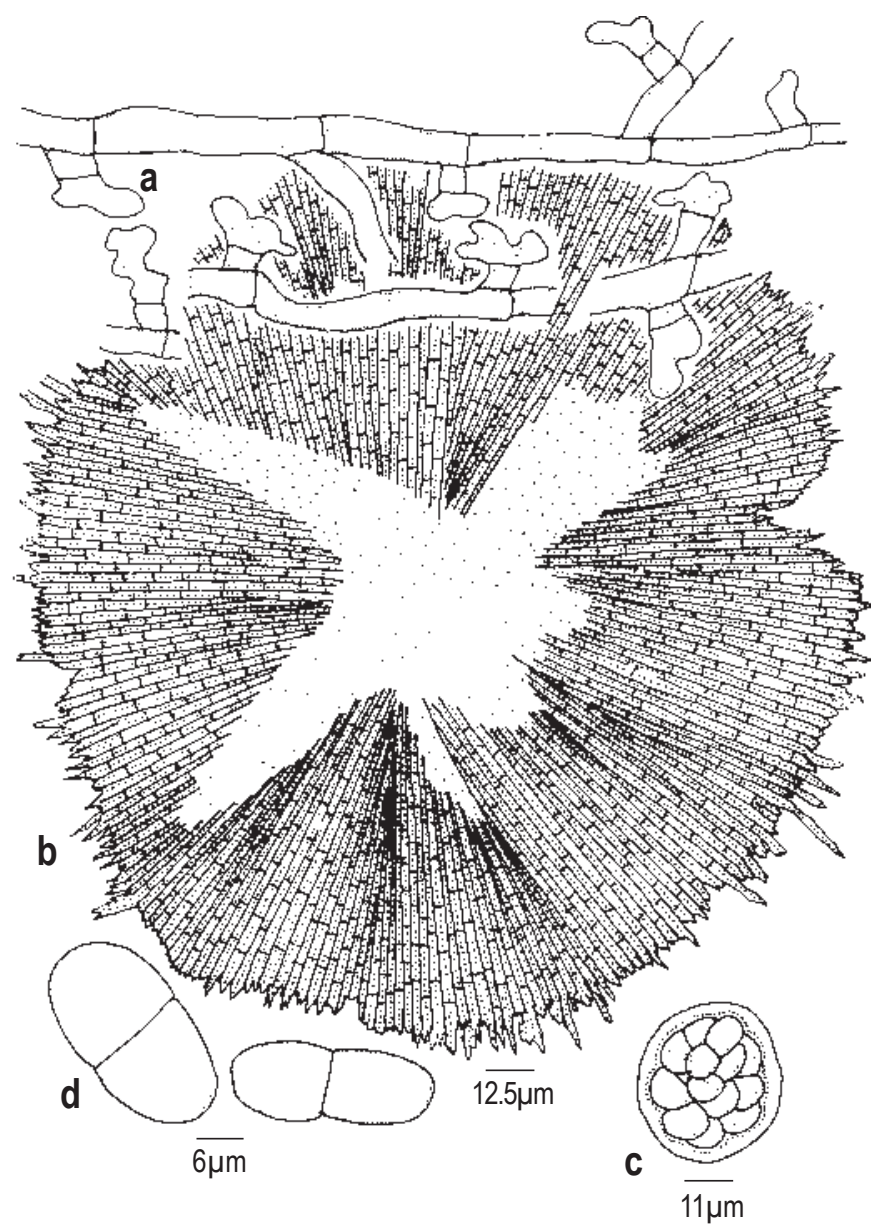

Figure 2. Asterina samaderae sp. nov a - Appressoriate mycelium; b - Thyriothecium; c - Ascus; d - Ascospores anfractuae, irregulariter acuteque vel laxe ramosae, laxe reticulatae, cellulae 20-28 × 3-5 $\mu \mathrm{m}$. Appressoria dispersa, alternata, unilateralis, ad 5\% opposita, antrorsa, subantrorsa, retrorsa, 9-13 $\mu \mathrm{m}$ longa; cellulae basalis cylindraceae vel cuneatae, 3-5 $\mathrm{m}$ longae; cellulae apicalis ovatae, oblongae, conoideae, globosae, integrae, angularis, bifidae vel et fortiter lobatae, rectae vel varie curvulae, 6-8 $x$ 4$10 \mu \mathrm{m}$. Thyriothecia dispersa vel laxe aggregata, orbicularis, ad $250 \mu \mathrm{m}$ diameter, margine crenatae vel leniter fimbriatae, hyphae fringiorae breviter, stellato dehiscentes ad centro; asci pauci, globosi, octospori, 30$40 \mu \mathrm{m}$ diameter; ascosporae oblongae, conglobatae, brunneae, uniseptatae, leniter constrictae, 25-30 x 11$13 \mu \mathrm{m}$.

Colonies hypophyllous, subdense, water soaked, spreading, 
up to $5 \mathrm{~mm}$ in diameter, confluent. Hyphae straight, substraight to crooked, branching irregular at acute to wide angles, loosely reticulate, cells 20-28 x 3-5 $\mu \mathrm{m}$. Appressoria scattered, alternate, unilateral, up to $5 \%$ opposite, antrorse, subantrorse, retrorse, $9-13 \mu \mathrm{m}$ long; stalk cell cylindrical to cuneate, 3-5 $\mu \mathrm{m}$ long; head cells ovate, oblong, conoid, globose, entire, angular, bifid to variously and deeply lobate,

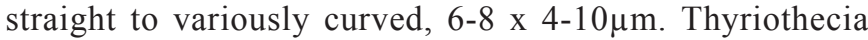
scattered to loosely grouped, orbicular, up to $250 \mu \mathrm{m}$ in diameter, margin crenate to slightly fimbriate, fringed hyphae small, stellately dehisced at the centre; asci few, globose, octosporous, 30-40 $\mu \mathrm{m}$ in diameter; ascospores oblong, conglobate, brown, 1-septate, slightly constricted at the septum, 25-30 x 11-13 $\mu \mathrm{m}$, wall smooth.

\section{Remarks}

Asterina lobata Sydow \& Sydow is known on the host Picrasma philippensis of Simaroubaceae from Philippines (Sydow \& Sydow, 1912; Hosagoudar \& Abraham, 2000). However, Asterina samaderae differs from it in having twocelled appressoria and larger ascospores.

\section{Acrodictys balladynae (Hansf.) M.B. Ellis \\ Dematiaceous Hyphomycetes, p. 129, 1971.}

(Fig. 3)

Acrospeira balladynae Hansf., Proc. Linn. Soc. London 157: 40, 1945.

\section{Material examined}

5.ii.2002, Chandanathode forest, Wyanad, Kerala, India on Balladyna sp. infected leaves of Pavetta sp. (Rubiaceae), coll. M. Kamarudeen, HCIO 44515, TBGT 801.
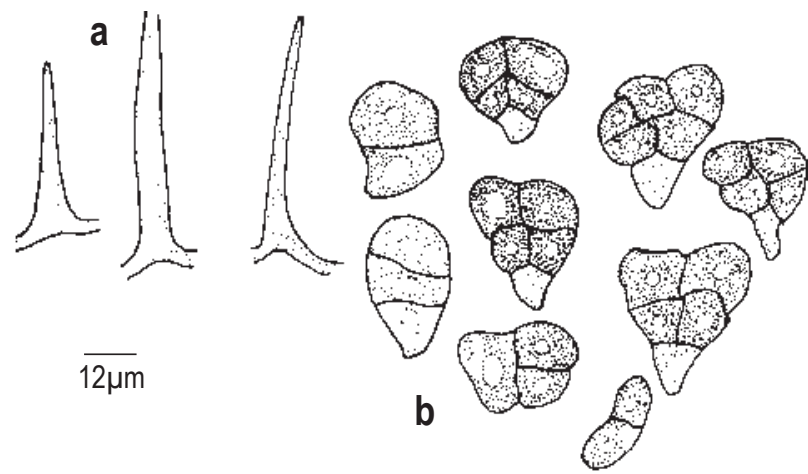

Figure 3. Acrodictys balladynae (Hansf.) M.B. Ellis a - Conidiophores; $b$ - Conidia

\section{Diagnostic features}

Colonies amphigenous, mostly hypophyllous, dense, crustose to velvety, up to $5 \mathrm{~mm}$ in diameter. Hyphae superficial, pale, branched, septate, $1.5-2.5 \mu \mathrm{m}$ broad. Conidiophores macronematous, mononematous, simple, cinnamon brown, erect, straight, smooth, rarely septate, slightly tapering towards apex, $30-40 \mu \mathrm{m}$ long; $3-5 \mu \mathrm{m}$ broad at the base; $1.5-$ $3 \mu \mathrm{m}$ broad at the tip. Conidia solitary, dry, terminal, obpyriform, clavate, broadly triangular, brown to black, upper stratum with 2-3-cells, second stratum with two cells and the lowest basal cell pale, $17-20 \mu \mathrm{m}$ long; $13-15 \mu \mathrm{m}$ broad at the upper portion, $9-12 \mu \mathrm{m}$ broad at the second cell layer and up to $3 \mu \mathrm{m}$ broad at the basal cell.

\section{Remarks}

This species was known from Ghana, Sierra Leone and Uganda (Ellis, 1971) and is reported here for the first time from India (Bilgrami et al., 1991).

\section{Lembosia ormosiae Yamamoto}

Sci. Rep. Hyogo Univ. Agric., Agric. Biol. Ser. II. 3: 28, 1957 (Fig. 4)

\section{Material examined}

24.iv.2002, in the campus of Tropical Botanic Garden and Research Institute, Palode, Thiruvananthapuram, Kerala, India, on leaves of Ormosia travancorica Beddome (Fabaceae), coll. T. Sabu, HCIO 44643, TBGT 925.

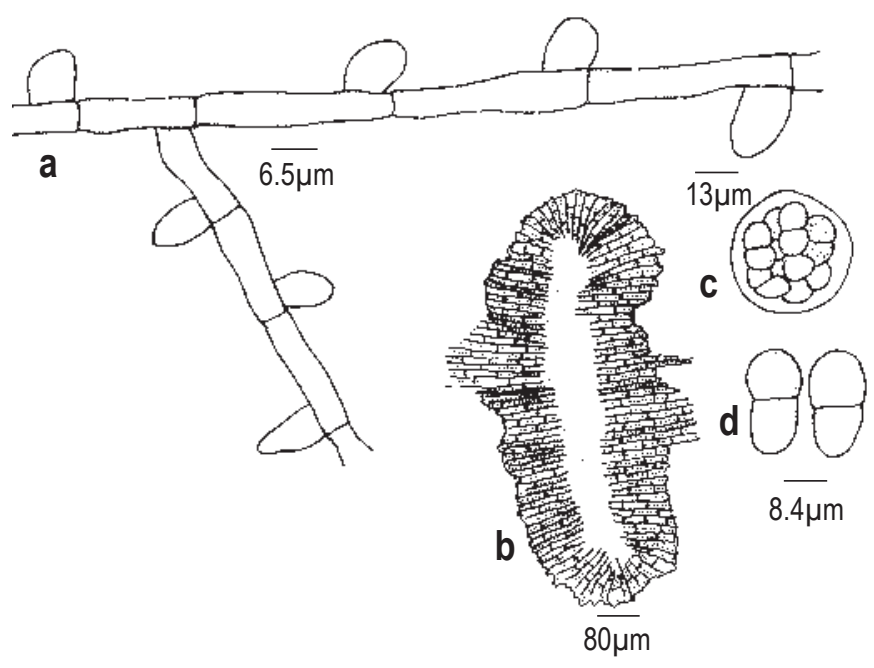

Figure 4. Lembosia ormosiae Yamamoto a - Appressoriate mycelium; b - Thyriothecium; c - Ascus; d - Ascospores 


\section{Diagnostic features}

Colonies epiphyllous, dense, crustose, up to $2 \mathrm{~mm}$ in diameter, confluent. Hyphae straight to substraight, branching opposite to irregular at acute to wide angles, loosely to closely reticulate, cells 19-24 x 4-6 $\mu \mathrm{m}$. Appressoria alternate, unilateral, rarely about $1 \%$ opposite, ovate, globose, mammiform, truncate to attenuated at the apex, straight to curved, entire to angular to rarely slightly sublobate, $6-10 \mathrm{x}$ $6-8 \mu \mathrm{m}$. Thyriothecia scattered, loosely grouped to rarely connate, straight to curved, 400-800 x 70-90 $\mu \mathrm{m}$, dehisce vertically at the centre, margin fimbriate to crenate; asci globose, octosporous, $35-40 \mu \mathrm{m}$ in diameter; ascospores oblong, conglobate, brown, uniseptate, slightly constricted at the septum, 19-21 x 7-9 $\mu \mathrm{m}$, wall smooth.

\section{Remarks}

This species was known on Ormosia formosana from Taiwan (Yamamoto, 1957) and is reported here for the first time from India on hitherto unrecorded host.

\section{Spiropes dialii (Bat.) Ellis}

Dematiaceous Hyphomycetes, p. 256, 1971.

(Fig. 5)

\section{Materials examined}

1.ix.2002, in the forest near Kushavoor, Palode, Thiruvananthapuram, Kerala, on the colonies of Meliola smilacis, on the leaves of Smilax sp. (Smilacaceae), coll. A. Manojkumar, HCIO 44588, TBGT 875.

\section{Diagnostic features}

Colonies dark, velvety, up to $2 \mathrm{~mm}$ in diameter. Synnemata scattered, simple, straight, erect, up to $1176 \mu \mathrm{m}$ long, up to $50 \mu \mathrm{m}$ broad at the base, up to $20 \mu \mathrm{m}$ broad in the middle and up to $50 \mu \mathrm{m}$ broad at the apex, conidiophores spread at the apex of the synnemata, conidia fusiform, obclavate, bottle shaped, 3-septate, rostrate, $24-40 \mu \mathrm{m}$ long, the two middle cells up to $8 \mu \mathrm{m}$ broad, apical cell beaked, up to $3 \mu \mathrm{m}$ broad, base hinged, up to $3 \mu \mathrm{m}$ broad.

\section{Remarks}

This fungus is known here for the first time from India (Bilgrami etal., 1991).

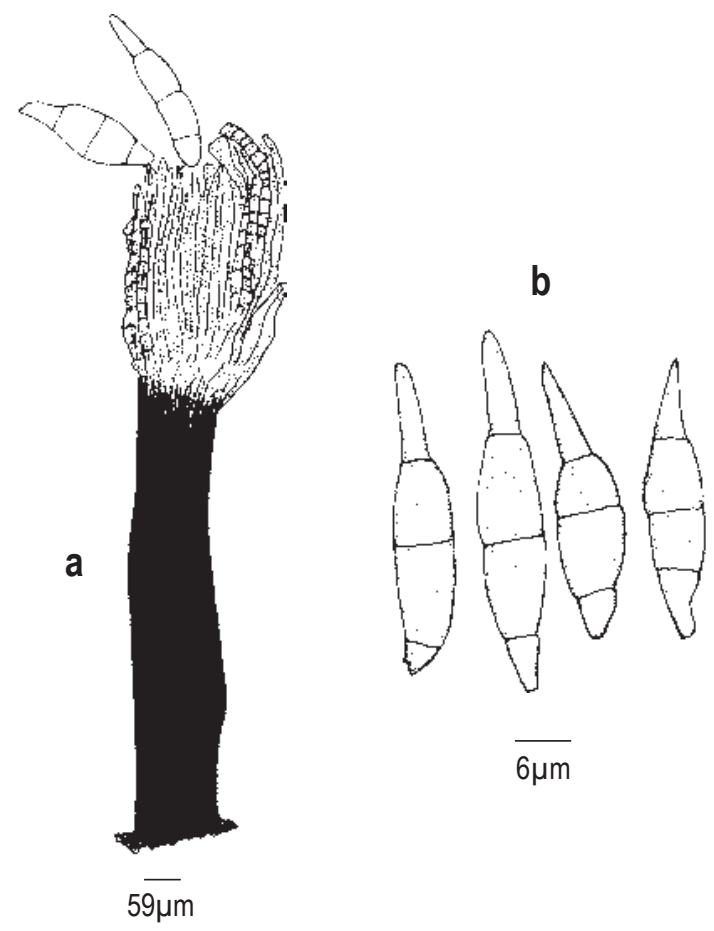

Figure 5. Spiropes dialii (Bat.) Ellis a - Synnematum; b - Conidia

\section{Acknowledgements}

Thanks are due to Dr. G.M. Nair, Director and Dr. T.K. Abraham, Deputy Director, TBGRI, Palode for the facilities.

\section{References}

Bilgrami, K.S., S. Jamaluddin and M.A. Rizwi (1991). Fungi of India: List and References. Today and Tomorrow's Printers \& Publishers, New Delhi, 798pp.

Ellis, M.B. (1971). Dematiaceous Hyphomycetes. Commomwealth Mycological Institute, Kew, Surrey England, 608pp.

Hosagoudar, V.B. and T.K. Abraham (2000). A list of Asterina Lev. species based on the literature. Journal of Economic and Taxonomic Botany 24: 557-587.

Hosagoudar, V.B., N.P. Balakrishnan and R.D. Goos (1996). Some Asterina species from southern India. Journal of Economic and Taxonomic Botany 59: 167-187.

Ryan, R. (1928). Asterina sp. from India. Memoirs of Department of Agriculture of India, Botany 15: 103-105.

Sydow, H. and P. Sydow (1912). Fungi from the Island of Palawan. Leaflets Philippine Botany 5: 1533-1547.

Yamamoto, W. (1957). The Formosan species of the Microthyriaceae - II. Science Report Hyogo University Agriculture, Agriculture Biological Series 3: 23-31. 